\title{
Dependence of the migratory activity of fish in the lake-river complex of Western Siberia on seasonal fluctuations in the hydrochemical parameters
}

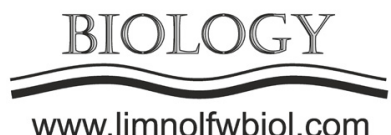

www.limnolfwbiol.com

\author{
Yadrenkina E.N. ${ }^{1,2}$ \\ ${ }^{1}$ Institute of Systematics and Ecology of Animals, Siberian Branch of the Russian Academy of Sciences, Frunze Str., 11, Novosibirsk, \\ 630091, Russia, Yadrenkina@ngs.ru \\ ${ }^{2}$ Novosibirsk State Agricultural University, Dobroljubova Str.,160, Novosibirsk, 630039, Russia
}

\begin{abstract}
The results of the analysis of long-term data on the spatial distribution of fish in the large shallow lake-river system of Western Siberia indicate their high seasonal migratory activity. The direction of fish movement to spawning areas is oriented along the desalination gradient in spring. During the feeding season, different species of fish congregate on spatially separated places of the lake, occupying different ecological niches. In winter, the lake's fish complex is localized at the deepest pools, it allows to survive under increasing of ice thickness and hypoxia condition. The high migratory activity of fish in the lake complex provides optimal using of the water area in seasonal fluctuation of hydrochemical parameters.
\end{abstract}

Keywords: fish community, migrations, environment fluctuation, Chany Lake, Western Siberia

Chany is the largest lakes system of lakes in the southern territory of the West Siberian Plain. It has no river runoff and therefore it reflects changes in the transgressive and regressive phase in changing of water level. According to the spatial displacement vectors - "tributaries $\rightarrow$ Malye Chany Lake $\rightarrow$ Chany Lake"- gradients of such vital characteristics as the water salinity, $\mathrm{pH}$, the ratio of gases dissolved in water - $\mathrm{O}^{2} \uparrow, \mathrm{CO}_{2} \uparrow$ and $\mathrm{CH}_{4} \uparrow$ have unidirectional character (Smirnova, 1982; Zhekhnovskaya, 1982; Pon'ko, 1986). Changing features of the hydrological, hydrochemical and thermal regimes, respectively, affect the spatial distribution, abundance, biomass, species composition of aquatic organisms and, in particular, fish (Yadrenkina et al., 2010; Yadrenkina, 2012a; Yadrenkina, 2012b). The "pulsation" of the lake affects the changes in biological processes that occur at different parts of the lake and its tributaries. Therefore, this reservoir is very convenient as a testing ground for studying the spatial and temporal dynamics of hydrobiont populations.

Most of the fish that live in the internal lakes of Western Siberia are freshwater, however, the resistance of various species to salinity is not the same. Only two native species can spawn in the brackish waters of Lake Chany: roach Rutilus rutilus and perch Perca fluviatilis. Nine species spawn in the desalinated part of Lake Maly Chany and its tributaries: pike Esox lucius, ide Leuciscus idus, dace L. leuciscus, roach Rutilus rutilus, goldfish Carassius carassius, crucian C. auratus, gudgeon Gobio gobio, tench Tinca tinca, perch Perca fluviatilis . Fish of the river complex can successfully reproduce at a salinity of not more than $0.5 \mathrm{~g} \cdot \mathrm{l}^{-1}$.

The results of many years of research have shown that the spawning grounds of local fish of the lake complex - ide, roach, perch - are confined to the river system and sections of the lake where the salinity of the water does not exceed $1.0 \mathrm{~g} \mathrm{l}^{-1}$. The distribution of spawning grounds of alien species - bream Abramis brama, carp Cyprinus carpio, pike perch Sander lucioperca are wider. These species can reproduce not only in Malye Chany Lake, but in Chany Lake also in conditions of water salinity up to $2.0 \mathrm{~g}^{-1}$.

The vast bays of estuarian zone between tributaries and lake are combined into a zone where reproductively significant parts both lake and river fish complexes overlap. Multi-ton schools of fish concentrate on this relatively limited territory during the breeding season, which determines the extremely high importance of the estuarian zone for the reproduction of the most populations and the fish productivity of the reservoir fish as a whole. Since the feed base of the "transition zone" cannot provide the nutritional needs of breeding fish, thee representatives of the lake complex after spawning move to the lake immediately.

In summer, the feeding areas of ide, roach, carp, pikeperch, perch are located both at lake and river biotopes, but gudgeon, dace, tench and verkhovka are distributed in river only. 
In the autumn period, as water temperature decreases, the feeding activity of fish decreases too, and they begin to move to the deepest areas of Chany Lake by winter.

Wintering grounds for fish are localized in the northeastern and southwestern basins of Lake Chany, and these waters are characterized by a sufficient concentration of dissolved oxygen for the survival of fish under ice cover.

The river fish are characterized by low migration activity. The rheophilous fish complex is very sensitive to oxygen concentration; therefore, it is in the river system for all seasons and never moves to the lake.

At the same time, the active exit of fish schools from the estuary zone for several months contributes to the restoration of their food supply, which ensures the successful reproduction, feeding and high level of juvenile fish survival, as well as high ecosystem productivity. Thus, high migration activity, a flexible response of fish to environmental fluctuations provide optimal dynamics of the spatial distribution (in this case, seasonality).

Summarizing the multifaceted information on the spatial and temporal dynamics of the distribution of fish throughout the basin, it is necessary to note the equivalence both the lake and river systems for the successful implementation of the life cycle of the lake fish complex to ensure high ichthyomass, as a whole. All of the above applies to the regulatory mechanisms of fish movement through the lake, their "fit" into varied set of qualitative parameters of spatially separated areas.

Thus, the intra-annual distribution of fish is associated with a complex of factors that limit the spatial localization of spawning, feeding and wintering areas. They are the next:

1. The vector of fish movements to spawning sites direct along gradient of water desalination in spring.

2. Most schools of fish return to the lake after spawning. At the same time, feeding of different fish species takes place in spatially separated areas of the water area, which reduces competition for food resources in the summer months.

3. In winter the development of hypoxia in shallow areas of the lake in winter blocks the ability of fish moving under the ice. Therefore, the food base of fish can be restored in places of spawning and feeding (to next year) from October to April.

4. The high migratory activity of fish in the lake complex, the flexible response of fish to environment fluctuations ensure rational using of water space and high fish productivity of the Chany Lake.

Over the past 30 years, the percent of alien species into ichthyofauna has increased many times and exceeded $50-\%$ of the total number of fish.

At present time the destroying processes under alien fish influence iare realy dangerous to keep balance in the regulatory of the spatial organization of the native species.

The author is grateful to the staff of ISEA SB RAS - Yuri Scherbakov, Alexander Scherbakov and Anna Scherbakova, as well as Ph.Dr. Andrei Yadrenkin for invaluable assistance in collecting and processing material.

\section{References}

Pon'ko V.A. 1986. Vodokhozyaystvennyy ocherk ozera Chany. In: Ioganzen B.G., Krivoshchekov G.M. (Eds.), Ekologiya ozera Chany [Ecology of Chany Lake]. Novosibirsk, pp. 11-27. (in Russian)

Smirnova N.P. 1982. Kratkaya fiziko-geograficheskaya kharakteristika oz. Chany. In: Smirnova N.P., Shnitnikov A.V. (Eds.), Pul'siruyushcheye ozero Chany. Leningrad, pp. 5-14. (in Russian)

Yadrenkina E.N. 2012a. Distribution of alien fish species in lakes within the temperate climatic zone of Western Siberia. Russian Journal of Biology Invasions 3: 145-157. DOI: $10.1134 /$ S2075111712020117

Yadrenkina E.N. 2012b. Current trends in the transformation of the fish species richness of the lake complex of Western Siberia within the temperate climate zone. Rybovodstvo i Rybnoe Khozyaystvo [Fish Farming and Fisheries] 7: 15-19. (in Russian)

Yadrenkina E.N., Interesova E.A., Babueva R.V. 2010. Ikhtiokompleksy ozer pri cheredovanii transgressivnoregressivnykh faz. In: Ravkin Yu.S. (Ed.), Bioraznoobraziye Karasuksko-Burlinskogo regiona (Zapadnaya Sibir'). Novosibirsk, pp. 87-195. (in Russian)

Zhekhnovskaya L.F. 1982. Osobennosti gidrokhimii ozera Chany. In: Smirnova N.P., Shnitnikov A.V. (Eds.), Pul'siruyushcheye ozero Chany. Leningrad, pp. 198-215. (in Russian) 